\title{
Preliminary Findings of New Citrus Rootstocks Potentially Tolerant to Foot Rot Caused by Phytophthora
}

\author{
Lidia Aparicio-Durán *(D), Juan M. Arjona-López (D), Aurea Hervalejo (D), Rocío Calero-Velázquez \\ and Francisco J. Arenas-Arenas
}

check for

updates

Citation: Aparicio-Durán, L.; Arjona-López, J.M.; Hervalejo, A.; Calero-Velázquez, R.; Arenas-Arenas, F.J. Preliminary Findings of New Citrus Rootstocks Potentially Tolerant to Foot Rot Caused by Phytophthora. Horticulturae 2021, 7, 389. https:// doi.org/10.3390/horticulturae7100389

Academic Editor: María

José Rubio-Cabetas

Received: 3 September 2021

Accepted: 4 October 2021

Published: 11 October 2021

Publisher's Note: MDPI stays neutral with regard to jurisdictional claims in published maps and institutional affiliations.

Copyright: (c) 2021 by the authors. Licensee MDPI, Basel, Switzerland. This article is an open access article distributed under the terms and conditions of the Creative Commons Attribution (CC BY) license (https:// creativecommons.org/licenses/by/ $4.0 /)$.
Department of Agri-Food Engineering and Technology, Andalusian Institute of Agricultural and Fisheries Research and Training (IFAPA), "Las Torres” Center, Ctra. Sevilla-Cazalla de la Sierra km. 12.2, Alcalá del Rio, 41200 Seville, Spain; juanm.arjona@juntadeandalucia.es (J.M.A.-L.); aurea.hervalejo@juntadeandalucia.es (A.H.); rocio.calero@juntadeandalucia.es (R.C.-V.); fjose.arenas@juntadeandalucia.es (F.J.A.-A.)

* Correspondence: lidia.aparicio@juntadeandalucia.es

\begin{abstract}
Phytophthora spp. are one the most common soil-borne pathogens in citrus crops, in which Phytophthora nicotianae and P. citrophthora are the most relevant species, causing disease problems worldwide, such as foot rot and gummosis of the trunk, branch canker, brown rot of fruit, feeder root rot in orchards, and seedling damping-off in nurseries. Phytophthora-tolerant citrus rootstocks are essential for its control and for the success of the citrus industry. The aim of this study was to determine the susceptibility of new citrus rootstocks with low HLB incidence to Phytophthora diseases. Thus, plants of several commercial and new citrus rootstocks originating in different breeding programs were inoculated with an isolate of $P$. nicotianae. Thirty days post inoculation (DPI), the damage of lesion length in stem was measured for each plant. These results displayed a different susceptibility response to the damage caused by P. nicotianae among the citrus rootstocks tested. Thus, eleven new citrus rootstocks (B11R3T25, B11R5T25, B11R5T49, B11R5T60, B11R5T64, N40R1T18, N40R1T19, N40R3T25, WGFT + 50-7, UFR-6, and CL-5146), which have not been previously studied against Phytophthora diseases, improved the tolerance effect of Carrizo citrange. Our findings provide useful information for citrus growers on rootstock selection to address incidence problems caused by Phytophthora spp.
\end{abstract}

Keywords: breeding; citriculture; citrus diseases; crop protection; Phytophthora diseases; plant tolerance

\section{Introduction}

The citrus industry has a great influence on Spanish agriculture. Spain is the top citrus producing country in the European Union and the sixth in the world, with a total production of over six million tons [1].

Phytophthora spp. are the most serious soil-borne pathogens of citrus trees worldwide, and they usually inhabit these crop soils. Ten species of this genus have been described as the causal agents of several citrus diseases, such as foot rot and gummosis of the trunk, branch canker, brown rot of fruit, feeder root rot in orchards, and seedling damping-off in nurseries [2-7]. Nevertheless, P. nicotianae (syn. P. parasitica) Dastur and P. citrophthora (R.E. Sm. \& E.H. Sm.) Leonian are the most widespread and relevant species worldwide [5].

Foot rot and gummosis disease infection processes increase under rainy conditions with warm temperatures $\left(20-25^{\circ} \mathrm{C}\right)$. Phytophthora propagules can splash from the soil to the trunk through rain drops near the ground level, infecting wounds or growth cracks that produce plant tissue lesions along the trunk [8]. These infections typically initiate at the base of the trunk. Typical symptoms of this disease in trees include growth flush reduction, defoliation, and twig dieback. When the disease is aggressive, infected trees can die, which occurs more frequently in younger than old trees [6].

Phytophthora spp. management has usually been carried out with systemic fungicides from the group of phosphonates (Fosetyl-Al) and phenylamide (metalaxyl), which generate 
colonization protection against $P$. nicotianae and P. citrophthora for three months $[9,10]$. However, new environmental trends in European agriculture are conducive to reduce the use of synthetic pesticides and lowering the presence of residues in food, with greater safety from chemical products for growers, and to avoid the emerging risk of pathogen resistance [11,12], such as species of Phytophthora [13]. In this sense, there is an additional need to shift agriculture towards sustainable methods that reduce supplies and costs.

In addition, cultural practices can be implemented in citrus orchards to reduce the incidence of diseases caused by Phytophthora spp. Thus, citrus growers apply different techniques to reduce excess water in the soil by means of drainage practices or an optimal irrigation dosage, as rainy and waterlogging conditions foster growth of this pathogen and dispersion and infection of its propagules to plant material [14]. These techniques play an important role in reducing propagation and development of the pathogen zoospores (main infective propagules) and mycelia, respectively. While Phytophthora spp. can produce other types of propagules, such as chlamydospores and oospores, which are potentially infective for plants, they mainly operate as latent structures of survival with a viability lasting several years. Thus, the use of pathogen-free plant material and disinfection of agricultural equipment and soil are required to avoid the occurrence of these resistant propagules [15]. However, all these cultural techniques are not fully implemented by growers and entail time-consuming and laborious works.

On the other hand, a proper choice of healthy and Phytophthora spp.-tolerant citrus rootstock has been reported as an essential factor to avoid these diseases in newly established orchards, as the rootstock confers tolerance to the whole plant against this pathogen [16]. Trifoliate orange (Poncirus trifoliata (L.) Raf.) and its hybrid Swingle citrumelo (Citrus paradisi $\times$ P. trifoliata) have been described as tolerant to $P$. nicotianae; nevertheless, they are not demonstrated to be tolerant against P. palmivora. On the other hand, Citrus volkameriana is also reported as tolerant to P. nicotianae [17], and Carrizo citrange (Poncirus trifoliata $\mathrm{x}$ Citrus sinensis), which is the most commonly cultivated rootstock in Spain (approximately $61 \%$ of citrus orchards) [18], is described as having an intermediate level of tolerance to Phytophthora spp. [19]. On the contrary, other citrus rootstocks, such as Cleopatra mandarin (Citrus reshni Hort. ex Tan.) and Rough Lemon (Citrus jambhiri), are described as Phytophthora spp.-sensitive rootstocks $[19,20]$. In addition, the occurrence risk of emerging diseases, such as Huanglongbing or citrus greening disease (HLB), have increased in the Iberian Peninsula, due to the dispersal in Spain and Portugal of Trioza erytreae [21,22], which is one of the most important insect vectors of the HLB causal agents [23]. Currently, a wide range of commercial citrus rootstocks are available to citrus growers, and in recent years breeding programs are generating new plant material for the citrus industry. To our knowledge, many of these new citrus rootstocks with reported low disease incidence of HBL have not been evaluated against Phytophthora diseases yet. The main aim of this work was, therefore, to assess tolerance to foot rot caused by Phytophthora in new citrus rootstocks originating in different breeding programs.

\section{Materials and Methods}

\subsection{Plant Material and Experimental Design}

Fourteen-month-old citrus plants belonging to twenty-four different rootstocks from in vitro culture were provided by the Agromillora Group nursery (Subirats, Barcelona, Spain) (Table 1). The study was divided into two experiments due to the high plant number and production. Each experiment was carried out in the 2020 and 2021 spring seasons, respectively, as previous described [24], under greenhouse conditions $\left(26^{\circ} \mathrm{C}\right.$ average temperature and $96 \%$ average relative humidity) located at the Las Torres Center in the Andalusian Institute for Agricultural and Fisheries Research and Training (IFAPA) in Alcalá del Río, Seville, Spain ( $\left.37^{\circ} 30^{\prime} 43.3^{\prime \prime} \mathrm{N} ; 5^{\circ} 57^{\prime} 47.4^{\prime \prime} \mathrm{W}\right)$. For each experiment, plants from each rootstock were separated into two treatments [inoculated and control (non-inoculated) plants], with eight replicates for inoculated plants and eight plants for non-inoculated. In all experiments, Carrizo citrange was used as the reference-comparative rootstock. Each 
plant was grown in 1.6-L pots with a mix of one part of silica sand and two parts of peat moss substrate (Sphagnum moss, wood fiber, and perlite; Gramoflor; Vechta, Germany) kept under an acclimation period of eight months and irrigated with water thrice per week depending on water requirements, non-nutritive solution was applied. Before starting the experiment, plants were distributed under a randomized block design.

Table 1. Citrus rootstocks assayed against foot rot disease.

\begin{tabular}{|c|c|c|c|c|}
\hline Rootstocks & Parentals & Ploidy & Origin & Ref. \\
\hline Carrizo citrange & Poncirus trifoliata $\times$ Citrus sinensis & $2 x$ & & [25] \\
\hline Citrus macrophylla & Citrus macrophylla & $2 x$ & & [26] \\
\hline Forner-Alcaide No. 5 & 'Cleopatra' mandarin x P. trifoliata & $2 x$ & IVIA & [27] \\
\hline UFR-1 & Nova + HBP $\times$ Cleopatra + Arg trifoliata & $4 x$ tetrazyg & CREC & [28] \\
\hline UFR-4 & Nova + HBP $\times$ Cleopatra + Arg trifoliata & $4 x$ tetrazyg & CREC & [29] \\
\hline UFR-5 & Changsha mandarin $+50-7$ trifoliate orange & $4 x$ tetrazyg & CREC & [30] \\
\hline UFR-6 & 'Changsha' mandarin + Trifoliate orange 5 & $4 x^{0}$ & CREC & [31] \\
\hline WGFT+ 50-7 & White grapefruit + Trifoliate orange 50-7 & $4 \mathrm{x}$ & CREC & [32] \\
\hline B11R3T24 & P. trifoliata x 'Duncan' grapefrutit & $2 x$ & CREC & \\
\hline A + Volk $\times$ Orange19-11-8 & $\begin{array}{c}\text { C. volkameriana } \times(\text { 'Nova' }+\mathrm{HBP} \times \text { 'Cleopatra' mandarin }+ \\
\text { Argentine trifoliate })\end{array}$ & $4 x$ tetrazyg & CREC & [33] \\
\hline $\mathrm{AMB}+\mathrm{CZO}$ & C. amblycarpa + Carrizo citrange & $4 x$ & CREC & [34] \\
\hline B11R5T25 & P. trifoliata $\times$ 'Duncan' grapefruit & $2 x$ & CREC & \\
\hline N40R1T18 & P. trifoliata x LB 1-21 (Clementine x 'Duncan' grapefruit) & $2 x$ & CREC & \\
\hline $2247 \times 2075-01-2$ & 'Nova' + HBP $\times$ 'Cleopatra' mandarine + Swingle Citrumelo & $4 x$ tetrazyg & CREC & \\
\hline N40R2T19 & P. trifoliata $\times$ LB 1-21 (Clementine x 'Duncan' grapefruit) & $2 x^{-0}$ & CREC & \\
\hline N40R3T25 & Flying Dragon $\times$ LB 1-21 (Clementine $x$ 'Duncan' grapefruit) & $2 x$ & CREC & \\
\hline B11R3T53 & ('Cleopatra' mandarin $\times$ C. ichangensis) $\times$ USD & $2 x$ & CREC & \\
\hline B11R5T49 & Flying Dragon $\times$ Ridge Pinneapple sweet orange & $2 x$ & CREC & \\
\hline B11R5T60 & Flying Dragon $\times$ Ridge Pinneapple sweet orange & $2 x$ & CREC & \\
\hline CL-5146 & C. sunki $\times$ C.Wingie & $2 x$ & CIRAD & \\
\hline $2247 \times 6070-02-2$ & Nova + HBP $\times$ Sour orange + P. trifoliata & $4 x$ tetrazyg & CREC & \\
\hline Orange-14 & Nova + HBP $\times$ Cleopatra + Arg trifoliate orange & $4 x$ tetrazyg & CREC & [35] \\
\hline B11R3T27 & Flying Dragon $\times$ duncan grapefruit & $2 x$ & CREC & \\
\hline B11R5T64 & Flying Dragon $\times$ Ridge Pinneapple sweet orange & $2 x$ & CREC & \\
\hline
\end{tabular}

2x: diploid; $4 \mathrm{x}$ : tetraploid somatic hybrid; $4 \mathrm{x}$ tetrazyg (origin from crosses of allotetraploid somatic hybrids); CREC: Citrus Research and Education Center (Florida, USA); CIRAD: Centre de Coopération Internationale en Recherche Agronomique pour le Développement (France). Ref.: References.

\subsection{Isolate of Phytophthora}

The isolate of Phytophthora (Pn1) was supplied from the fungal collection of Instituto Valenciano de Investigaciones Agrarias (IVIA). DNA identification was carried out to confirm the genus and specie of this oomycete. First, the isolate was grown over cellophane membrane on Petri dishes (60 $\mathrm{mm}$ of diameter) with potato-dextrose-agar (15 mL, PDA, Biokar diagnostics, Solabia Group, Cedex, France) and incubated under chamber conditions $\left(25^{\circ} \mathrm{C}\right.$ in darkness) for ten days. Next, the isolate was sent to a commercial laboratory (Agricultura y Ensayo S.L.; Alcalá de Guadaira, Seville, Spain) for DNA extraction, PCR amplification, and sequencing. Briefly, DNA extraction process was carried out following the manufacturers' instructions of HigherPurity ${ }^{\mathrm{TM}}$ Plant DNA Purification Kit (Canvax Biotech, S.L., Cordoba, Spain). PCR amplification and further sequencing of the Internal Transcribe Spacer (ITS) region of the nuclear rDNA was carried out with ITS1 and ITS4 primers [36]. The PCR reactions were mixed in a total volume of $25 \mu \mathrm{L}$ containing DNA product, $0.8 \mathrm{mM}$ dNTPs, $2.5 \mathrm{mM} \mathrm{MgCl} 2$, 1X PCR Buffer, $0.75 \mu \mathrm{M}$ of each primer, and $0.05 \mathrm{U} / \mu \mathrm{L}$ of Horse-Power-Taq DNA polymerase (Canvax Biotech, S.L., Cordoba, Spain), conducted in a BT1 Thermocycler (Whatman Biometra, Göttingen, Germany) with an initial step of denaturation at $95^{\circ} \mathrm{C}$ for $5 \mathrm{~min}$, followed by amplification of 35 cycles of $30 \mathrm{~s}$ at $95^{\circ} \mathrm{C}$, annealing $45 \mathrm{~s}$ at $56^{\circ} \mathrm{C}$, and extension at $72{ }^{\circ} \mathrm{C}$ for $2 \mathrm{~min}$. The amplified fragments were visualized by electrophoresis in $2 \%$ agarose gel stained with RedSafe (iNtRON, Biotechnology, Inc., Korea). The PCR products were sequenced by a DNA commercial sequencing service (Secugen, S.L., Madrid, Spain). The raw sequences were edited using the Chromas 2.6.4 program (Technelysium Pty Ltd., South Brisbane, Australia), assembled by the DNAMAN 6.0.3.93 program (Lynnon Corporation, San Ramon, CA, USA) and 
compared with sequences from GenBank genetic sequence database using BLAST (version 1.17, Basic Local Alignment Search Tool, National Center for Biotechnology Information).

\subsection{Inoculation Process}

For the inoculation process in all experiments, Pn1 was grown for refreshing on $15 \mathrm{~mL}$ PDA Petri dishes and later incubated under chamber conditions for two weeks. Then, the groups of fourteen-month-old citrus plants were inoculated with Pn1. Disks of bark $5 \mathrm{~mm}$ in diameter were incised and cut from the stem of each plant with a sterile cork borer (5-mm diameter) at 30-35 cm above the ground from the rootstock trunks. Mycelial disks (with the same size and tool) were cut from the active PDA culture of Pn1 (Figure 1A) and inserted mycelial face inward into each hole stem section for inoculated plants. PDA disks (with the same size and tool) from non-cultured PDA petri dishes were cut and placed in each sliced stem section for control plants (non-inoculated). Each agar disk was covered with the bark disk (Figure 1B), held, and wrapped in place manually with a strip of cotton moistened with sterile water, and then covered around each stem with aluminum foil (Figure 1C). All inoculated and control plants were incubated under greenhouse conditions, and cotton layers were periodically watered for three days a week to keep the inoculum moist.
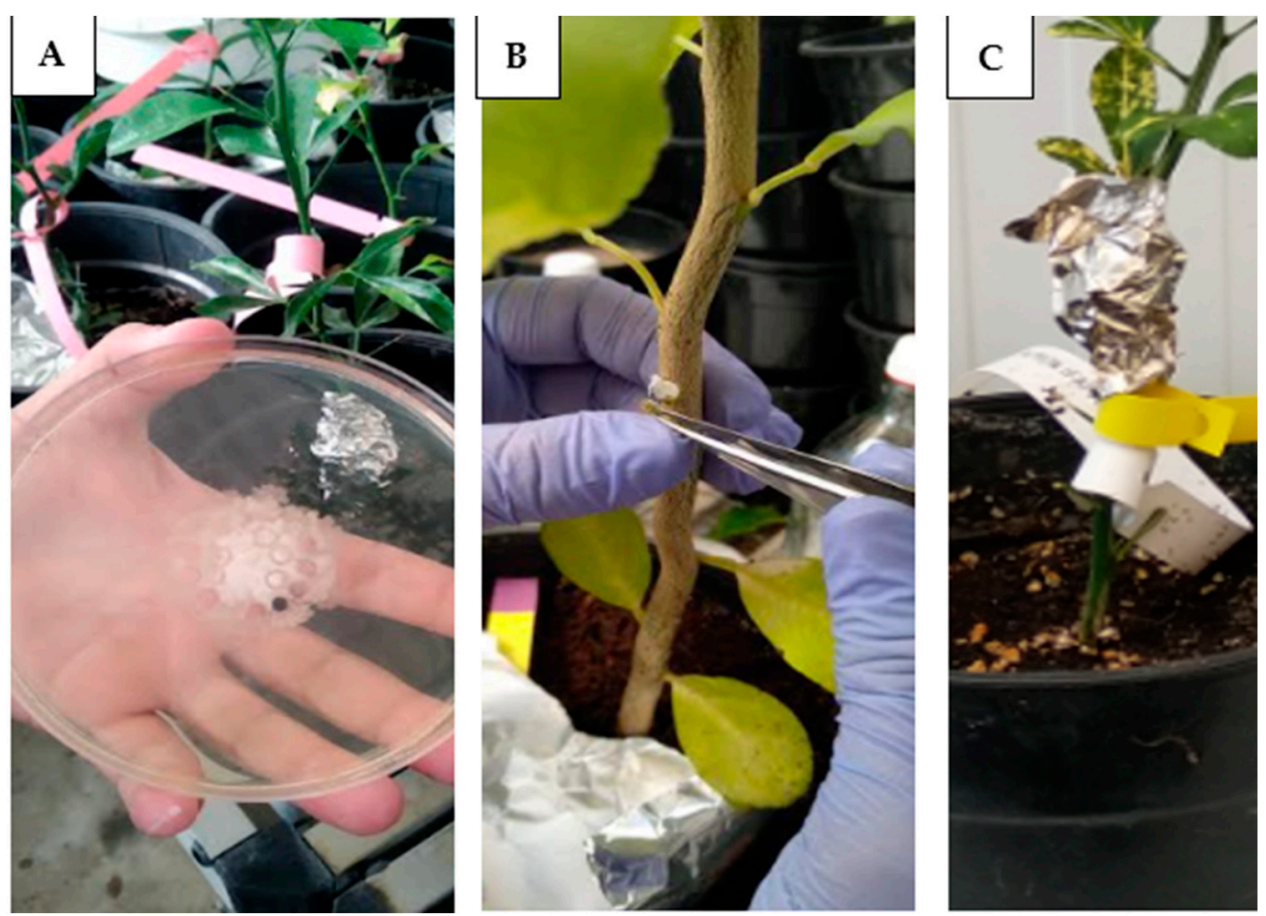

Figure 1. Phytophthora nicotianae inoculation process in stem of citrus plant: 5-mm mycelial disks of $P$. nicotianae in PDA petri dishes (A); P. nicotianae PDA mycelial disks on the citrus plant stem covering with a piece of citrus rootstock bark using laboratory tweezers (B); inoculated citrus plant covered with wet cotton (distilled water) and aluminum paper (C).

\subsection{Disease Evaluation and Data Analysis}

In all experiments, the aboveground symptoms of foot rot disease caused by Pn1 were evaluated for each citrus plant and treatment 30 DPI from the beginning of the experiment (inoculation day) (Figure 2). Next, all the wrappings were removed, all the rootstocks stems were cut $25-30 \mathrm{~cm}$ above and below the inoculation site, and each lesion length caused by Phytophthora inoculum was measured using an electronic digital slide gauge (Absolute digimatic caliper, Mitutoyo Corporation, Kawasaki, Japan). The level of rootstock tolerance was evaluated by comparing the lesion length of each. Thus, the values of lesions lengths were statistically analyzed using the free software $R$ version 4.0.2 [37], performing 
one-way ANOVA and LSD-Fisher tests $(p<0.05)$ for each experiment [38] with the package "agricolae" [39].
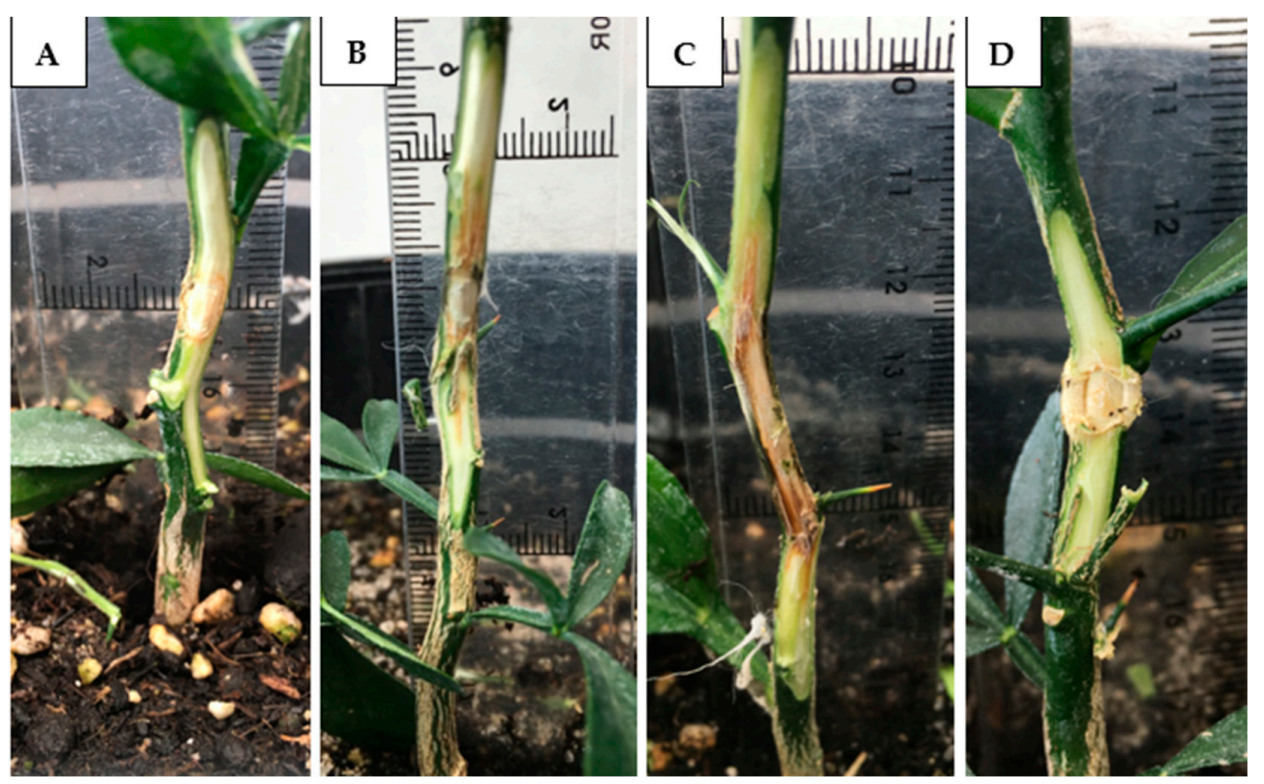

Figure 2. Foot rot lesion length level of $P$. nicotianae 30 days post inoculation in different rootstocks: UFR-6 (7.88 mm) (A); Carrizo citrange (24.03 mm) (B); $2247 \times 6070-02-2(43.57 \mathrm{~mm})($ C); cork borer lesion $(5.00 \mathrm{~mm})$ in non-inoculated UFR-6 (D).

\section{Results}

3.1. Molecular Identification of Phytophthora Isolate

The oomycete isolate (Pn1) used in this study was corroborated as P. nicotianae by sequencing of the ITS region. These sequences showed $96.78 \%$ identity with $P$. nicotianae upon BLAST match analysis (Supplementary Material).

\subsection{Tolerance Response of Rootstock to Foot Rot Disease}

A total of twelve different citrus rootstocks (Carrizo citrange, Citrus macrophylla, UFR4, $2247 \times$ 2075-01-2, A + Volk $\times$ orange, AMB + CZO, B11R3T24, B11R5T25, N40R11T18, N40R2T19, N40R3T25, and WGFT + 50-7) were assayed in the first experiment (spring of 2020). Citrus plants inoculated with $P$. nicotianae showed lesion length in the stem with significant response $\left(\mathrm{F}_{11,83}=51.60 ; p<0.001\right)$ among the rootstocks tested. On the contrary, citrus plants inoculated with PDA alone (without inoculum) did not show lesion length in the stem without statistical differences $\left(\mathrm{F}_{11,84}=1.12 ; p=0.35\right)$ among the rootstocks assayed. Hence, $2247 \times 2075-01-2$ was the citrus rootstock with the highest damage of lesion length in the stem $(21.83 \mathrm{~mm})$. This disease incidence was followed by Carrizo citrange $(18.11 \mathrm{~mm})$, A + Volk $\times$ Orange-E 19-11-8 (17.25 mm), and AMB + CZO (17.13 mm), without significant differences compared with $2247 \times$ 2075-01-2. An intermediate group of lesion length response was comprised of UFR-4 (15.83 mm), N40R1T18 (13.39 mm), Citrus macrophylla (12.69 mm), N40R2T19 (11.65 mm), and WGFT + 50-7 (11.29 mm), which showed statistical differences compared with the highest lesion length response. Lastly, the lowest significant incidence of lesion length was accomplished by N40R3T25 (8.16 mm), B11R5T25 (8.37 mm), and B11R3T24 (10.29 mm) (Figure 3). 


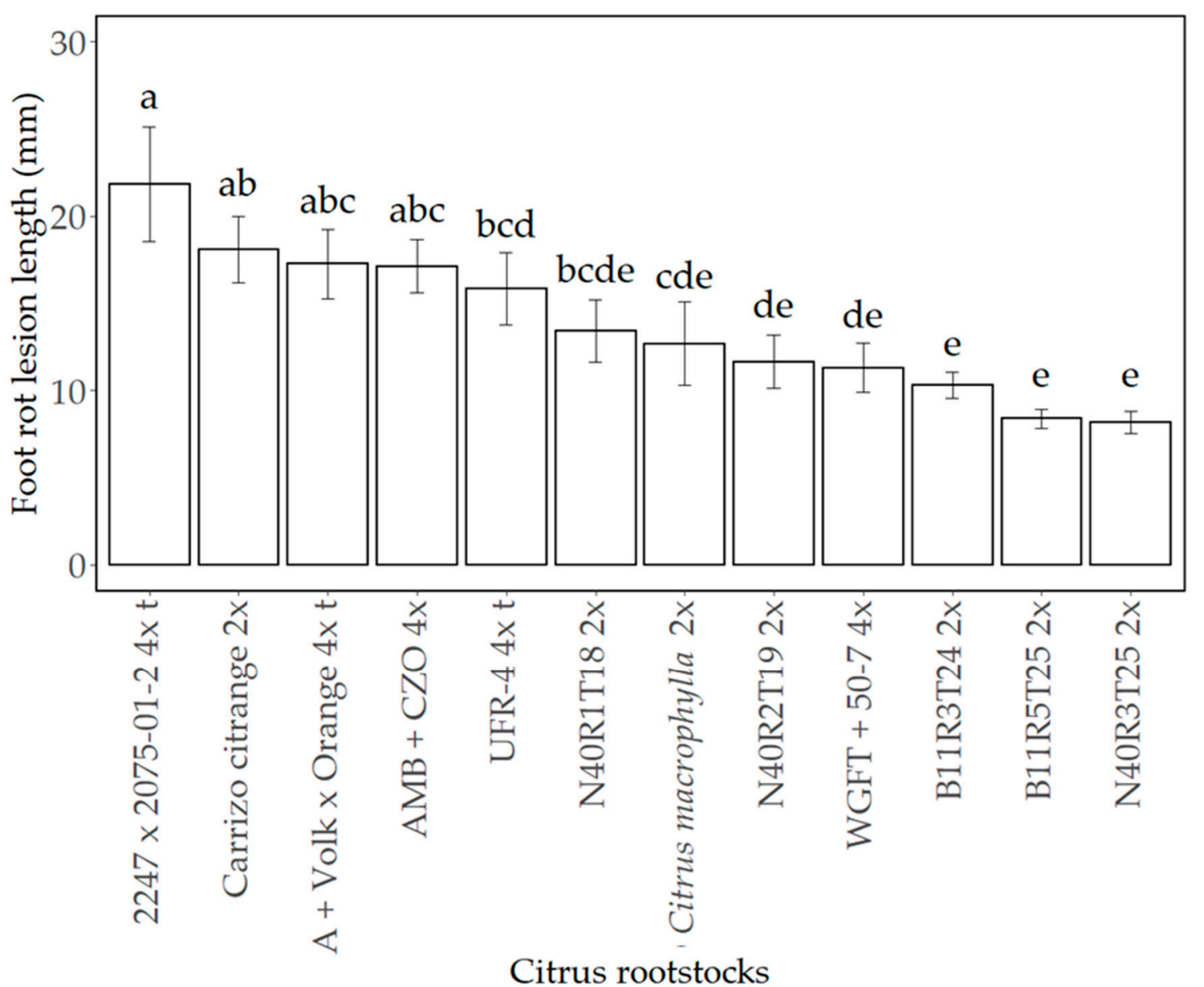

Figure 3. Mean foot rot lesion length response caused by P. nicotianae on twelve different citrus rootstocks tested during spring of 2020. Different letters above the bars indicate significant differences among the citrus rootstocks assayed ( $p<0.05)$. A + Volk x Orange: A + Volk x Orange19-11-8. Ploidy: 2x; 4x; 4x t: 4x tetrazyg.

In the second experiment (spring of 2021), a total of thirteen different rootstocks (Carrizo citrange, Forner-Alcaide No.5, Orange-14, UFR-1, UFR-5, UFR-6, CL-5146, $2247 \times 6070-02-2$, B11R3T27, B11R3T53, B11R5T49, B11R5T60, and B11R5T64) were tested for their response to foot rot disease. Citrus plants inoculated with $P$. nicotianae showed lesion length in the stem with significant response $\left(F_{12,91}=93.73 ; p<0.001\right)$ among the rootstocks tested. On the contrary, citrus plants inoculated with PDA alone (without inoculum) did not show lesion length in the stem without statistical differences $\left(\mathrm{F}_{12,91}=1.32\right.$; $p=0.22$ ) among the rootstock assayed. Rootstock Orange-14 reported the highest value of lesion length $(35.14 \mathrm{~mm})$, which was followed by $2247 \times 6070-02-2(32.21 \mathrm{~mm})$, UFR5 (30.52 mm), and UFR-1 $(29.43 \mathrm{~mm})$, without statistical differences compared with the Orange-14 response. Otherwise, the lowest damage of lesion length was achieved by B11R5T64 $(9.16 \mathrm{~mm})$, followed by UFR-6 $(9.56 \mathrm{~mm})$, B11R5T60 $(10.86 \mathrm{~mm})$, CL-5146 $(14.28 \mathrm{~mm})$, and B11R3T53 $(14.96 \mathrm{~mm})$, without significant differences compared with the lowest response. An intermediate group of lesion length incidence was obtained by rootstocks B11R5T49 $(26.11 \mathrm{~mm})$, B11R3T27 $(23.60 \mathrm{~mm})$, Carrizo citrange $(22.16 \mathrm{~mm})$, and Forner-Alcaide No. $5(17.80 \mathrm{~mm})$, showing statistical differences compared with the highest and the lowest response of lesion length (Figure 4). 


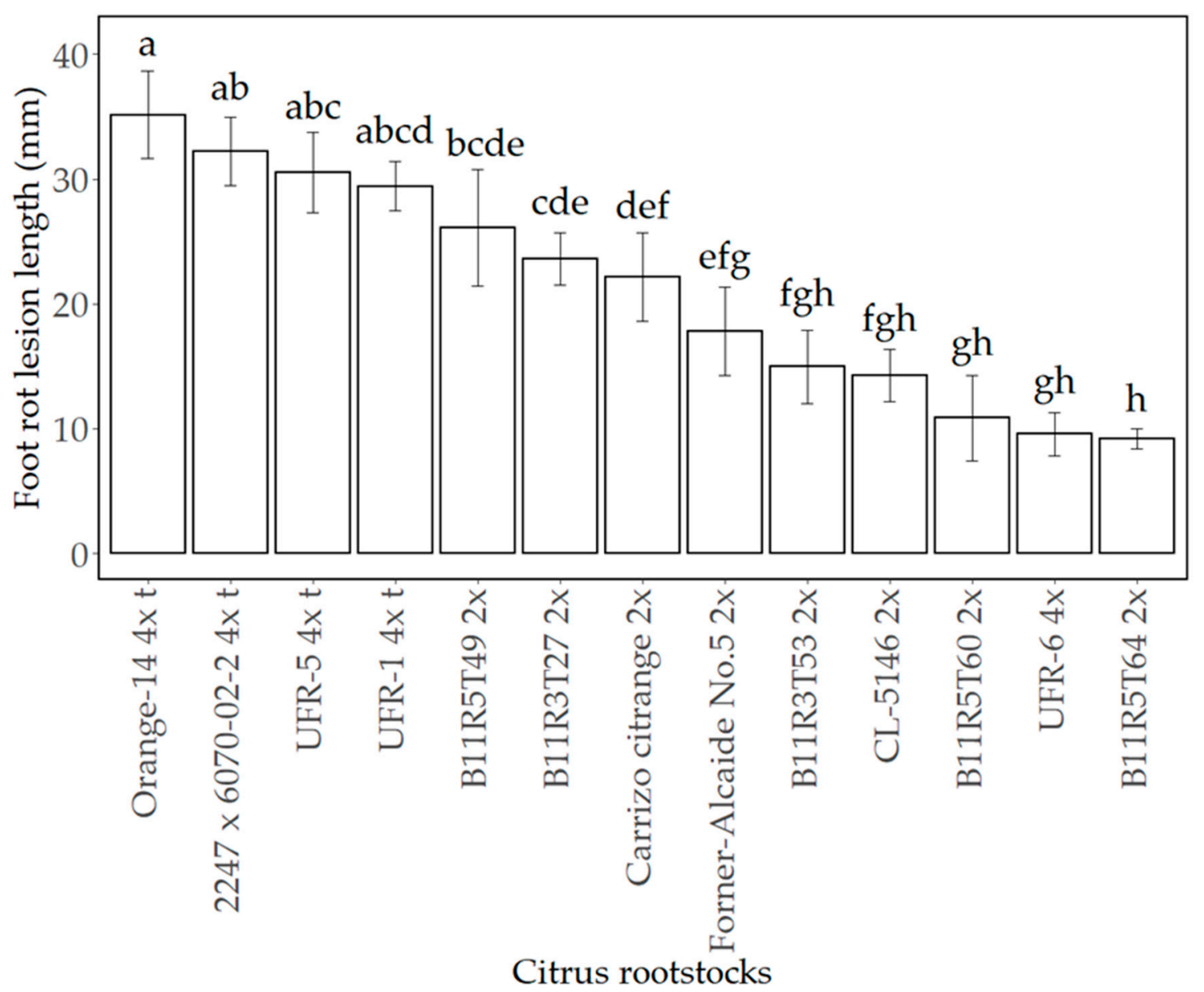

Figure 4. Mean foot rot lesion length response caused by P. nicotianae on thirteen different citrus rootstocks tested during spring of 2021. Different letters above the bars indicate significant differences among the citrus rootstocks assayed $(p<0.05)$. Ploidy: 2x; $4 x ; 4 x$ t: $4 x$ tetrazyg.

\section{Discussion}

Our findings provide information about the tolerance response to foot rot lesion length in the stem caused by P. nicotianae among new different citrus rootstock, which is described as one of the most relevant Phytophthora species causing citrus diseases, such as foot rot and gummosis of the trunk [6,40]. To our knowledge, the disease incidence caused by Phytophthora on new citrus rootstocks has not been researched recently.

Prior studies have reported Carrizo citrange as having known tolerance and weakness against P. nicotianae and P. palmivora, respectively [16]. Otherwise, other authors have described an intermediate tolerance to diseases caused by Phytophthora spp. However, five recently obtained citrus rootstocks (N40R2T19, WGFT + 50-7, B11R3T24, B11R5T25, and N40R3T25) improved the tolerance behavior of $C$. macrophylla in the 2020 experiment (Figure 3). In the latest experiment, Forner-Alcaide No. 5 rootstock improved the tolerance response of Carrizo citrange, but five others recently obtained citrus rootstocks (B11R3T53, CL-5146, B11R5T60, UFR-6, and B11R5T64) displayed a lower P. nicotianae incidence than Forner-Alcaide No. 5 (Figure 4). In this sense, previous authors have reported tolerance to Phytophthora spp. on Forner-Alcaide No. 5 rootstock [41].

Furthermore, UFR-1, UFR-4, UFR-5, and UFR-6 have been previously described as tolerant to Phytophthora spp. [19]. However, we only identified UFR-6 as being tolerant to P. nicotianae in our results. Thus, UFR-4 displayed an intermediate tolerance response to P. nicotianae, higher than Carrizo citrange, but more sensitive than C. macrophylla. UFR-1 and UFR-5 were reported as having a high level of susceptibility to P. nicotianae, with a similar response to $2247 \times 6070-02-2$ and Orange-14. Lastly, ten recently obtained citrus 
rootstocks were found with low level of damage caused by P. nicotianae. To the best of our knowledge, the behavior towards P. nicotianae by these ten candidates (B11R3T24, B11R5T25, B11R3T53, B11R5T60, B11R5T64, N40R1T18, N40R1T19, N40R3T25, WGFT + 50-7, and CL-5146) has not been previously reported; after these preliminary results, all of these citrus rootstocks will be included for future field research of susceptibility against Phytophthora diseases. On the other hand, ten citrus rootstock tested in this work are tetraploid, in which UFR-6, WGFT + 50-7, and AMB + CZO are somatic hybrids, while UFR-1, UFR-4, UFR-5, $2247 \times 2075-01-2,2247 \times 6070-02-2$, A-Volk $\times$ Orange 19$11-8$, and Orange 14 are tetrazyg [42]. From these tetraploid rootstocks, only UFR-6 and WGFT + 50-7 reported a high tolerance level to P. nicotianae, similar to other diploid citrus rootstocks. Furthermore, most of these new rootstocks have been tested against emerging diseases such as Huanglongbing or citrus greening disease (HLB); hence, some commercial ones are reported with low HLB incidence (UFR-1, UFR-4, and UFR-6) [19] and other new citrus rootstocks have preliminary displayed low HLB incidence (B11R3T24, B11R3T27, B11R5T25, B11R3T53, B11R5T49, B11R5T60, B11R5T64, N40R1T18, N40R2T19, and N40R3T25) [personal communication, F.G. Gmitter Jr.], in which seven rootstocks from this last group are included as the highest tolerance against foot rot disease in the present work.

\section{Conclusions}

Cultivation of citrus rootstocks tolerant to diseases caused by Phytophthora spp. is the most effective methodology to reduce these damages. Our results provide preliminary helpful information for citrus growers to perform an accurate selection of rootstocks in those areas where Phytophthora causes serious damage to citrus crops. Thus, this first screening work indicates that eleven new citrus rootstocks, namely, B11R3T24, B11R5T25, B11R3T53, B11R5T60, B11R5T64, N40R1T18, N40R1T19, N40R3T25, WGFT + 50-7, UFR-6, and CL-5146, are potential candidates to be taken into account to solve problems triggered by these diseases. These preliminary results are helpful for the citrus industry to increase the rootstock variability of their orchards, and for the research community and breeding programs aiming for future improvements in this field. Consequently, further studies will involve the field susceptibility of all twenty-four citrus rootstocks against damages caused by Phytophthora spp.

Supplementary Materials: The following are available online at https:/ /www.mdpi.com/article/ 10.3390/horticulturae7100389/s1, Sequence 1: Pn1 (950 bp).

Author Contributions: Conceptualization, F.J.A.-A.; Methodology, L.A.-D., J.M.A.-L., R.C.-V., and F.J.A.-A.; Software, L.A.-D. and J.M.A.-L.; Validation, F.J.A.-A. and A.H.; Formal analysis, L.A.-D., J.M.A.-L., and R.C.-V.; Investigation, L.A.-D., J.M.A.-L., and F.J.A.-A.; Resources, F.J.A.-A.; Data curation, L.A.-D., J.M.A.-L., and R.C.-V.; Writing-original draft preparation, L.A.-D. and J.M.A.-L.; Writing-review and editing, L.A.-D., J.M.A.-L., A.H., and F.J.A.-A.; Supervision, F.J.A.-A.; Project administration, F.J.A.-A. All authors have read and agreed to the published version of the manuscript.

Funding: This research was funded by the research contract CEM 38/2018 Agromillora Catalana and the project "Network of Experimentation and Transfer, and the research in Andalusian Citrus (PR.TRA.TRA2019.001.001)", which was co-financed (80\%) by the European Regional Development Fund within the FEDER Operational Program of Andalusia 2014-2020.

Institutional Review Board Statement: Not applicable.

Informed Consent Statement: Not applicable.

Data Availability Statement: Not applicable.

Acknowledgments: We are highly thankful to Frederick G. Gmitter Jr., Jude W Grosser, and Agromillora Group for providing the plant material. The authors are also highly grateful to Antonio Vicent and Jose Luis Mira for providing the Phytophthora nicotianae isolate (Pn1). The authors are grateful to FPI-INIA 2016 grant (CPD2016-0130). 
Conflicts of Interest: The authors declare no conflict of interest.

\section{References}

1. FAOSTAT, 2021. Food and Agriculture Organization (FAO) of the United Nations. Available online: http://www.fao.org/faostat/ es/\#home (accessed on 15 March 2021).

2. Afek, U.; Sztejnberg, A.; Solel, Z. A rapid method for evaluating citrus seedlings for resistance to foot rot caused by Phytophthora citrophthora. Plant Dis. 1990, 74, 66-68. [CrossRef]

3. Matheron, M.E.; Matejka, J.C. Seasonal differences in susceptibility of three citrus rootstocks to root lesions caused by Phytophthora citrophthora and P. parasitica. Plant Dis. 1993, 77, 729-732. [CrossRef]

4. Bowman, K.D.; Albrecht, U.; Graham, J.H.; Bright, D.B. Detection of Phytophthora nicotianae and P. palmivora in citrus roots using PCR-RFLP in comparison with other methods. Eur. J. Plant Pathol. 2007, 119, 143-158. [CrossRef]

5. Erwin, D.C.; Ribeiro, O.K. Phytophthora Diseases Worldwide; American Phytopathological Society (APS Press): St. Paul, MN, USA, 1996; ISBN 0890542120.

6. Alvarez, L.A.; Vicent, A.; De la Roca, E.; Bascón, J.; Abad-Campos, P.; Armengol, J.; García-Jiménez, J. Branch cankers on citrus trees in Spain caused by Phytophthora citrophthora. Plant Pathol. 2007, 57, 84-91. [CrossRef]

7. Alvarez, L.A.; Gramaje, D.; Abad-Campos, P.; García-Jiménez, J. Seasonal susceptibility of citrus scions to Phytophthora citrophthora and P. nicotianae and the influence of environmental and host-linked factors on infection development. Eur. J. Plant Pathol. 2009, 124, 621-635. [CrossRef]

8. Graham, J.H.; Menge, J.A. Root diseases. In Citrus Health Management; Timmer, L.W., Duncan, L.W., Eds.; American Phytopathological Society: St. Paul, MN, USA, 1999; pp. 126-135.

9. Matheron, M.E. Persistence of systemic activity for fungicides applied to citrus trunks to control Phytophthora gummosis. Plant Dis. 1988, 72, 170. [CrossRef]

10. Adaskaveg, J.E.; Hao, W.; Förster, H. Postharvest strategies for managing Phytophthora brown rot of citrus using potassium phosphite in combination with heat treatments. Plant Dis. 2015, 99, 1477-1482. [CrossRef] [PubMed]

11. De Waard, M.A.; Georgopoulos, S.G.; Hollomon, D.W.; Ishii, H.; Leroux, P.; Ragsdale, N.N.; Schwinn, F.J. Chemical control of plant diseases: Problems and prospects. Annu. Rev. Phytopathol. 1993, 31, 403-421. [CrossRef]

12. Gullino, M.L.; Kuijpers, L.A.M. Social and political implications of managing plant diseases with restricted fungicides in Europe. Annu. Rev. Phytopathol. 1994, 32, 559-581. [CrossRef]

13. Timmer, L.W.; Graham, J.H.; Zitko, S.E. Metalaxyl-resistant isolate of Phytophthora nicotianae: Occurrence, sensitivity, and competitive parasitic ability on citrus. Plant Dis. 1998, 82, 254-261. [CrossRef]

14. Dwiastuti, M.E. Citrus foot rot disease (Phytophthora spp.) control in Indonesia using good agricultural practices efforts green agroindustry. IOP Conf. Ser. Earth Environ. Sci. 2020, 484, 012097. [CrossRef]

15. Drenth, A.; Guest, D. Principles of Phytophthora disease management. In Diversity and Management of Phytophthora in Southeast Asia; Drenth, A., Guest, D., Eds.; Australian Centre for International Agricultural Research: Canberra, Australia, $2004 ;$ pp. 154-160.

16. Graham, J.; Feichtenberger, E. Citrus phytophthora diseases: Management challenges and successes. J. Citrus Pathol. 2015, 2, 1-11. [CrossRef]

17. Graham, J.H. Root regeneration and tolerance of citrus rootstocks to root rot caused by Phytophthora nicotianae. Phytopathology 1995, 85, 111-117. [CrossRef]

18. Tallón Vila, C.I. Biotechnology Applied to the Genetic Improvement of Citrus Rootstocks. Development of a Protocol for Micropropagation and Adventitious Regeneration for Use in Generating Salt Toleran Mutant Lines. Ph.D. Thesis, Universidad de Murcia, Murcia, Spain, 2015; p. 105.

19. Florida Citrus Rootstock Selection Guide, 4th Edition. 2021. Available online: https://crec.ifas.ufl.edu/extension/citrus_ rootstock/tables.html (accessed on 30 August 2021).

20. Bowman, K.D.; Joubert, J. Citrus rootstocks. In The Genus Citrus; Talon, M., Caruso, M., Gmitter, F.G., Eds.; Woodhead Publishing: Sawston, UK; Elsevier Inc.: Cambridge, MA, USA, 2020; pp. 105-127. ISBN 9780128121634.

21. Arenas-Arenas, F.J.; Duran-Vila, N.; Quinto, J.; Hervalejo, Á. Is the presence of Trioza erytreae, vector of huanglongbing disease, endangering the Mediterranean citrus industry? Survey of its population density and geographical spread over the last years. $J$. Plant Pathol. 2018, 100, 567-574. [CrossRef]

22. Arenas-Arenas, F.J.; Duran-Vila, N.; Quinto, J.; Hervalejo, Á. Geographic spread and inter-annual evolution of populations of Trioza erytreae in the Iberian Peninsula. J. Plant Pathol. 2019, 101, 1151-1157. [CrossRef]

23. Bové, J.M. Huanglongbing: A destructive, newly-emerging, century-old disease of citrus. J. Plant Pathol. 2006, 88, 7-37.

24. Alvarez, L.A.; Vicent, A.; Soler, J.M.; De la Roca, E.; Bascón, J.; García-Jiménez, J. Comparison of application methods of systemic fungicides to suppress branch cankers in clementine trees caused by Phytophthora citrophthora. Plant Dis. 2008, 92, 1357-1363. [CrossRef]

25. Vogel, R.; Bové, J.M. Réactions de quelques porte-greffe a l'exocortis. Fruits 1971, 26, 295-300.

26. Hodgson, R.W. Taxonomy and nomenclature in citrus. In Proceedings of the 2nd Conference of the International Organization of Citrus Virologists, Gainesville, FL, USA, 7-13 November 1960; pp. 1-7.

27. Forner, J.B.; Forner-Giner, M.A.; Alcaide, A.; Ten, C. Forner-Alcaide 5 and Forner-Alcaide 13: Two new citrus rootstocks released in Spain. HortScience 2003, 38, 629-630. [CrossRef] 
28. Grosser, J.W. Citrus rootstock named "UFR-1". U.S. Patent PP27,277; United States Plant Patent Application Publication, 18 October 2016.

29. Grosser, J.W. Citrus rootstock named “UFR-4". U.S. Patent 2015/0195974; United States Plant Patent Application Publication, 7 March 2017.

30. Grosser, J.W. Citrus rootstock named “UFR-5”. U.S. Patent PP27,298; United States Plant Patent Application Publication, 25 October 2016.

31. Grosser, J.W. Citrus rootstock named "UFR-6". U.S. Patent PP27,276; United States Plant Patent Application Publication, 20 August 2015.

32. Grosser, J.W.; Chandler, J.L.; Ling, P.; Barthe, G.A. New somatic hybrid rootstock candidates for tree-size control and high juice quality. In Proceedings of the Florida State Horticultural Society; Florida State Horticultural Society: St. Petersburg, FL, USA, 2011; Volume 124, pp. 131-135.

33. Grosser, B.J.; Gmitter, F.; Bowman, K.; Sciences, A. New Rootstocks in the Citrus Breeding Pipeline. Available online: https:/ / citrusindustry.net/2020/07/15/new-rootstocks-in-the-citrus-breeding-pipeline/ (accessed on 18 May 2021).

34. Grosser, J.W.; Ollitrault, P.; Olivares-Fuster, O. Somatic hybridization in citrus: An effective tool to facilitate variety improvement. In Vitro Cell. Dev. Biol. Plant 2000, 36, 434-449. [CrossRef]

35. Grosser, J.; Graham, J.; Hoyte, A. Continued development of rootstocks tolerant of the Phytophthora-Diaprepes complex via greenhouse screening. In Proceedings of the Florida State Horticultural Society; Florida State Horticultural Society: St. Petersburg, FL, USA, 2007; Volume 120, pp. 103-109.

36. White, T.J.; Bruns, T.; Lee, S.; Taylor, J. Amplification and direct sequencing of fungal ribosomal RNA genes for phylogenetics. In PCR Protocols: A Guide to Methods and Applications; Innis, M.A., Gelfand, D.H., Sninsky, J.J., White, T.J., Eds.; Academic Press, Inc.: San Diego, CA, USA, 1990; pp. 315-322.

37. R Development Core Team. R: A Language and Environment for Statistical Computing; R Foundation for Statistical Computing: Vienna, Austria, 2020; ISBN 3-900051-07-0. Available online: https:/ / www.r-project.org/ (accessed on 15 December 2020).

38. Steel, R.G.D.; Torrie, J.H. Principles and Procedures of Statistics: With Special Reference to the Biological Sciences; McGraw-Hill Book Company, Inc.: New York, NY, USA, 1960.

39. De Mendiburu, F. Statistical procedures for agricultural research. In Package "Agricolae", Version 1.4-Comprehensive R Archive Network; Institute for statistics and mathematics: Vienna, Austria, 2013.

40. Tuzcu, Ö.; Çinar, A.; Göksedef, M.O.; Özsan, M.; Biçici, M. Resistance of citrus rootstocks to Phytophthora citrophthora during winter dormancy. Plant Dis. 1984, 68, 502-505. [CrossRef]

41. Aleza, P.; Forner-Giner, M.A.; Del-Pino, Á. El panorama varietal y los nuevos patrones. Análisis de la situación actual. In Una Hoja de Ruta para la Citricultura Española; García Álvarez-Coque, J.M., Motló, E., Eds.; Cajamar Caja Rural: Almería, Spain, 2020; pp. 151-166.

42. Grosser, J.W.; Omar, A.A.; Gmitter, J.A.; Syvertsen, J.P. Salinity tolerance of 'Valencia' Orange trees on allotetraploid rootstocks. Proc. Fla. State Hortic. Soc. 2012, 125, 50-55. 